Rev. Latinoam. Psicopat. Fund., São Paulo, 17(4), 940-942, dez. 2014

http://dx.doi.org/10.1590/1415-4714.2014v17n4p940.12

Reverie e interpretação: captando algo humano

Thomas H. Ogden

São Paulo: Escuta, 2013, 256 págs. (Kultur)

\title{
A reverie nesta arte da psicanálise
}

\author{
Roosevelt M. S. Cassorla*
}

É impossível ler Thomas Ogden sem sonhar acordado. O leitor intui que está usufruindo de experiências emocionais que o tornam mais humano. O subtítulo de Reverie e interpretação - captando algo humano é revelador. Sonhamos e pensamos o mundo com nossas emoções, tecido conectivo que vincula as representações simbólicas. Emoções que se manifestam desesperadamente em busca de continentes que lhes deem significado, quando não puderam ser representadas. $\mathrm{O}$ humano participa da arte de transformar esse desconhecido desumano, e esta é a arte do psicanalista.

Sinta a vitalidade da frase "Debussy acreditava que música era o espaço entre as notas. Pode-se dizer algo similar da psicanálise. Entre as notas das palavras ditas, que constituem o diálogo analítico, estão as reveries do

* Universidade Estadual de Campinas - Unicamp (Campinas, SP, Br) e Grupo de Estudos Psicanalíticos de Campinas (Campinas, SP, Br) 


\section{RESENHA DE LIVROS}

analista e do analisando. Nesse espaço ocupado pelo interjogo de reveries é que se encontra a música da psicanálise". Com ela Ogden inicia um dos capítulos do livro.

A questão da vitalidade e da desvitalização está sempre presente em sua obra. $\mathrm{O}$ analista intui a vida e a falta de vida do paciente, de si mesmo e do processo analítico. A psicanálise contemporânea, da qual Ogden é um dos mais queridos e respeitados representantes, se ocupa das emoções e reveries, "espaço entre as notas", mais do que de palavras. Daquilo que seres humanos evocam, transmitem e provocam no outro (e em si mesmos).

A inexatidão, tanto na escrita como na fala do analista com seu paciente, é um recurso necessário na criação do espaço para o desconhecido. A falta de definições precisas, substituídas por experiências emocionais que se vivem enquanto se lê, torna a leitura de Ogden uma aventura onde o leitor se transforma, naturalmente, em parte do texto. Texto-a-dois, como os sonhos-a-dois que geram significados. Significados provisórios e volúveis que apontam para outros, num processo sem fim de desenvolvimento e reversões de rede simbólica.

A fluidez da reverie ("ruminações, devaneios, fantasias, sensações corporais, percepções fugazes, imagens emergindo dos estados de dormência, melodias e frases que atravessam nossas mentes, e assim por diante") se torna a bússola que o analista utiliza na experiência analítica. É necessário que o analista se perca ("fique à deriva") enquanto espera que, naturalmente, as reveries (que, enganosamente, parecem fruto da inadequação da função analítica) façam sentido.

O "terceiro analítico intersubjetivo", uma das intuições mais férteis de Ogden, revela que, entre paciente e analista, se cria um terceiro que difere de sua soma, interagindo dialeticamente com os membros da dupla. Os sonhos e as reveries que ocorrem no campo analítico são a-dois e, também, relativos a esse terceiro. Ogden nem sempre espera as associações dos analisandos que contam sonhos, porque os sonhos são também do analista. Instruir os pacientes a "falarem o que passa por sua mente" pode inibir sua espontaneidade e capacidade de reverie. Ogden nos desafia a repensar, o tempo todo, o "já sabido".

Ogden (a partir de Frost) disseca o valor e o poder da linguagem poética, fator da arte da psicanálise. Esta arte não é qualquer arte, é "esta" arte específica. Quando estamos com um paciente, num determinado momento, é com "este" paciente e "neste momento", momento da dupla analítica que nunca mais será vivido.

O leitor não familiarizado com esta psicanálise contemporânea poderá "ficar à deriva" durante a leitura das reveries descritas nos fascinantes relatos clínicos. É possível que a falta de questionamento reflita sedução acrítica pelo texto. Dúvidas tornarão o texto mais interessante.

Ogden parte de leituras originais de Freud e dos clássicos (Klein, Bion, Winnicott) rumo a sua própria originalidade. A psicanálise brasileira vem, cada vez mais, sendo influenciada por esta psicanálise, que não se filia a "escolas" que, 
necessariamente, desvitalizam a teoria e a prática. Ogden descreve a "linguagem emprestada" do psicanalista não espontâneo. O antigo preconceito (ideológico e político) em relação à psicanálise norte-americana, se ainda existe, é desfeito com a leitura de Thomas Ogden. Leitura que faz sonhar...

\section{Roosevelt M.S. Cassorla}

Analista Didata do Grupo de Estudos Psicanalíticos de Campinas (Campinas, SP, Br) e da Sociedade Brasileira de Psicanálise de São Paulo - SBPSP (São Paulo, SP, Br); Professor Titular Colaborador da Universidade Estadual de Campinas - Unicamp (Campinas, SP, Br); Membro do Conselho Editorial do International Journal of Psychoanalysis.

Av. Francisco Glicério, 2331/24 - Vila Itapura

13023-101 Campinas, SP

e-mail: rcassorla@uol.com.br 